\title{
Relationship of oral candidiasis with salivary lysozyme and lactoferrin in HIV-positive patients: a systematic review
}

\author{
Paria Motahari \\ Department of Oral Medicine, Faculty of Dentistry, Tabriz University of Medical Sciences, Tabriz, Iran
}

\begin{abstract}
Oral candidiasis is one of the main consequences of human immunodeficiency virus (HIV) infection. Saliva contains proteins that play a key role in the health of oral cavity. The aim of this review study was to investigate the relationship of oral candidiasis with salivary lysozyme and lactoferrin in patients with HIV infection. In this systematic review study, all articles with English abstract were searched with the keywords of "Oral Candidiasis" or "Candida" and "Saliva" and "HIV" or "AIDS" and "Lysozyme" and "Lactoferrin" from the Google Scholar, PubMed, Web of Science, Cochrane, and Scopus databases from 1990 until April 2020. Amongst the 16 articles obtained after reviewing the abstracts, 13 appropriate articles were included in this study. In 11 studies, the relationship between salivary lactoferrin and oral candidiasis was investigated, $54 \%$ of which showed an increase in salivary lactoferrin in HIV-positive patients with candidiasis. Eight studies examined the relationship between salivary lysozyme and oral candidiasis, $63 \%$ of which showed no association. Understanding numerous factors and conditions involved in candida cloning would be broadly related to increasing our understanding of fungal pathogenesis and host defense factors. The results of our study could be useful in diagnosing and designing new strategies for the prevention and treatment of fungal infections in HIV-positive patients. In addition to anti-fungal properties, non-toxicity to human cells could lead to lactoferrin being used in the future as a drug to prevent and treat fungal infections in patients with immunity difficulties.
\end{abstract}

HIV AIDS Rev 2021; 20, 1: 17-20

DOI: https://doi.org/10.5114/hivar.2021.105091

Key words: candidiasis, oropharyngeal, lactoferrin, lysozyme, HIV.

\section{Introduction}

Oral candidiasis is one of the most common fungal infections, which affects the oral mucosa [1]. Ninety percent of patients with acquired immune deficiency syndrome (AIDS) suffer from oropharyngeal candidiasis in many stages of their disease. Candida albicans is the major cause of oral candidiasis in patients with human immunodeficiency virus (HIV) and AIDS. With the development of HIV infection, despite the use of antifungal drugs prophylaxis, oral candidiasis becomes a permanent resident of the oral cavity. Extensive lesions of this infection can be painful and cause eating disorders and malnutrition, which is frequent in patients with AIDS [2-4].

Saliva plays an important role in maintaining oral health and prevents mouth candidiasis with two mechanisms. First, saliva is mixed with bacteria and debris, and by swallowing, these organisms are cleared from the oral cavity. Second, saliva contains anti-microbial proteins as lysozyme (murami-
Address for correspondence: Paria Motahari, Department of Oral Medicine, Faculty of Dentistry, Tabriz University of Medical

Sciences, Tabriz, Iran, e-mail: paria.motahari@yahoo.com
Article history:

Received: 07.07.2020

Received in revised form: 24.08 .2020

Accepted: 01.09.2020

Available online: 30.03 .2021
International Journal of HIV-Related Problems

HIV \& AIDS

R e v i e w 
dase) and lactoferrin, which are considered to regulate candida population in the oral cavity $[5,6]$. It should be noted that lysozyme is an enzymatic protein that some of researchers have shown to be anti-fungal in the oral cavity $[7,8]$. Lactoferrin is an iron-binding protein, which has proven in-vitro anti-fungal properties [9].

Changes in the host's salivary flow rate and composition during HIV infection may alter the host's defense mechanism that affects the candida's adhesion and cloning. Therefore, the increase of oral candidiasis in HIV-positive patients may be related to defects in salivary defense proteins [10].

Numerous studies have examined the association of salivary proteins with oral candidiasis. In one study, Muller et al. showed that a decrease in salivary lactoferrin and IgA was associated with an increase in recurrent oral fungal infections in HIV-positive patients [11]. Even though some researchers have reported no significant association, other studies have shown a direct relation between these proteins and candidiasis [12-15]. Giving such inconsistent conclusions in this regard, the aim of this review study was to investigate the oral candidiasis relationship with salivary lysozyme and lactoferrin in patients with HIV infection. Knowing this connection can be useful in diagnosing and designing new treatment strategies for the prevention and treatment of fungal infections in these patients.

\section{Material and methods}

\section{Search strategy}

This systematic review was conducted based on the preferred reporting items for systematic reviews and meta-analyses (PRISMA) statement for reporting systematic reviews [16].

A focused question was produced according to the participants, intervention, control, and outcomes (PICO) principles [17]. The focused question for this review was "Is there an association between oral candidiasis and salivary lysozyme and lactoferrin in HIV-positive patients?" In this

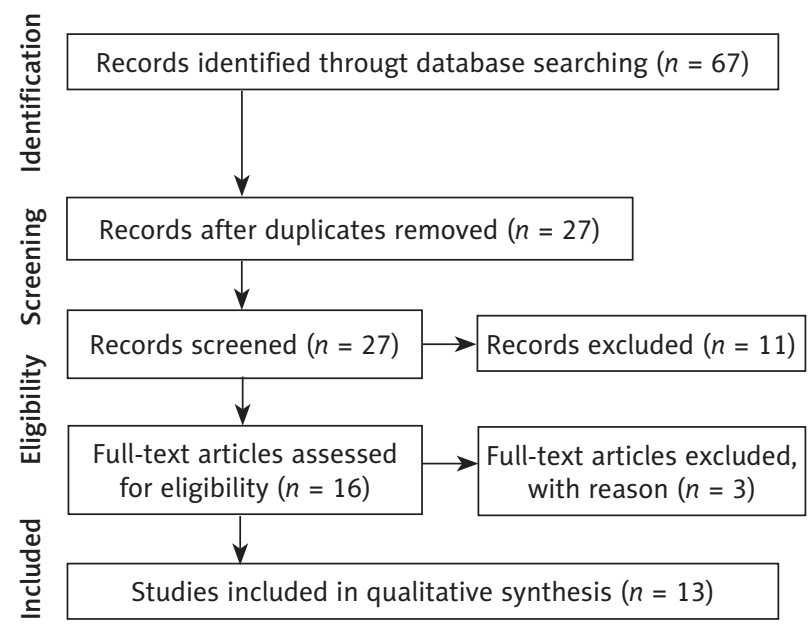

Figure 1. Flowchart of searching strategy based on PRISMA guidelines review study, all published articles with English abstract with the medical subject heading (MESH) terms and keywords of "Oral Candidiasis" or "Candida" and "Saliva" and "HIV" or "AIDS" and "Lysozyme" and "Lactoferrin" from Google Scholar, PubMed, Web of Science, Cochrane, and Scopus databases were searched from 1990 until April 2020. In the initial phase, the titles and abstracts of articles were reviewed by two independent individuals, based on inclusion and exclusion criteria. Disagreements were resolved with the third author's discussion. Next, the full text of selected articles was reviewed. The quality of chosen studies was evaluated by the Newcastle-Ottawa scale method [18]. The data of selected articles were extracted using data extraction form. This form included the author's name, year of publication, sample size, and the results of study.

\section{Inclusion criteria}

Inclusion criteria were the studies, in which levels of salivary lactoferrin or lysozyme in HIV-positive patients were assessed, and its association with oral candidiasis was evaluated.

\section{Exclusion criteria}

Reviews and case reports articles as well as in-vitro studies were excluded.

\section{Results}

During the initial search, 67 articles were obtained. Amongst 16 articles, after reviewing the abstracts, 13 appropriate articles were included in this study, based on the entry and exit criteria shown in Figure 1.

In 11 studies, the relationship between salivary lactoferrin and oral candidiasis was investigated, 54\% of which showed an increase in salivary lactoferrin in HIV-positive patients with candidiasis. In $37 \%$ of studies, no association between oral candidiasis and salivary lactoferrin in patients with HIV infection was indicated, and other studies revealed that oral candidiasis was associated with low levels of salivary lactoferrin in HIV-positive patients. Eight studies examined the relationship between salivary lysozyme and oral candidiasis, in which $63 \%$ showed no association, and $37 \%$ demonstrated an increase in salivary lysozyme in HIV-positive patients with candidiasis (Table 1).

\section{Discussion}

The results of this systematic review demonstrated that HIV-positive patients with higher candida counts had higher salivary lysozyme and lactoferrin, but the secretion of these salivary anti-microbial proteins was suppressed in HIV-positive patients, whose CD4+ cell counts were significantly lower.

In patients with HIV infection, oral candidiasis is still known to be one of the most common opportunistic infec- 
Table 1. Summary of data extracted from the studies included in this review

\begin{tabular}{|c|c|c|c|c|}
\hline Authors [ref] & Year & Study design & Sample size $[n]$ & Results \\
\hline $\begin{array}{l}\text { Chandrasekar } \\
\text { Lakshmi et al. [14] }\end{array}$ & 2016 & $\begin{array}{l}\text { Case-control } \\
\text { study }\end{array}$ & $\begin{array}{l}90 \text { HIV patients, } \\
30 \text { controls }\end{array}$ & $\begin{array}{c}\text { The levels of salivary lysozyme and candida count } \\
\text { were high in HIV-positive patients compared } \\
\text { to the control group, but there was no significant } \\
\text { relationship between them }\end{array}$ \\
\hline Ferreira et al. [15] & 2015 & $\begin{array}{l}\text { Case-control } \\
\text { study }\end{array}$ & $\begin{array}{c}28 \text { HIV patients, } \\
10 \text { controls }\end{array}$ & Lactoferrin levels were directly related to oral candidiasis \\
\hline Alves et al. [19] & 2014 & $\begin{array}{l}\text { Cross-sectional } \\
\text { study }\end{array}$ & $\begin{array}{l}70 \text { HIV patients, } \\
50 \text { controls }\end{array}$ & $\begin{array}{l}\text { HIV-positive patients had higher salivary lactoferrin levels } \\
\text { associated with candida cloning }\end{array}$ \\
\hline Lourenco et al. [12] & 2013 & $\begin{array}{l}\text { Case-control } \\
\text { study }\end{array}$ & $\begin{array}{l}69 \text { HIV patients, } \\
40 \text { controls }\end{array}$ & $\begin{array}{l}\text { There was no association between oral candidiasis and } \\
\text { salivary lactoferrin in HIV-positive patients }\end{array}$ \\
\hline Laibe et al. [20] & 2005 & $\begin{array}{l}\text { Case-control } \\
\text { study }\end{array}$ & $\begin{array}{l}19 \text { HIV patients, } \\
11 \text { controls }\end{array}$ & $\begin{array}{c}\text { Salivary lactoferrin and lysozyme levels were high in HIV- } \\
\text { positive patients with oral candidiasis }\end{array}$ \\
\hline Namikoshi et al. [21] & 2004 & $\begin{array}{l}\text { Case-control } \\
\text { study }\end{array}$ & $\begin{array}{l}30 \text { HIV patients, } \\
50 \text { controls }\end{array}$ & $\begin{array}{l}\text { The secretion of salivary anti-microbial proteins against } \\
\text { candidiasis increased in healthy individuals and HIV- } \\
\text { positive patients, but was suppressed in HIV-positive } \\
\text { patients whose CD4+ counts were significantly lower }\end{array}$ \\
\hline Bard et al. [22] & 2002 & $\begin{array}{l}\text { Case-control } \\
\text { study }\end{array}$ & $\begin{array}{c}19 \text { HIV patients, } \\
11 \text { controls }\end{array}$ & $\begin{array}{c}\text { HIV-positive patients with candidiasis infection had higher } \\
\text { salivary lactoferrin levels }\end{array}$ \\
\hline Lin et al. [23] & 2001 & Cohort study & $\begin{array}{l}18 \text { HIV patients, } \\
34 \text { controls }\end{array}$ & $\begin{array}{c}\text { There was no association between anti-candidiasis activity } \\
\text { and salivary lactoferrin and lysozyme }\end{array}$ \\
\hline $\begin{array}{l}\text { Van Der Strate } \\
\text { et al. [24] }\end{array}$ & 1999 & $\begin{array}{l}\text { Case-control } \\
\text { study }\end{array}$ & $\begin{array}{l}95 \text { HIV patients, } \\
26 \text { controls }\end{array}$ & $\begin{array}{c}\text { The presence of candidiasis was associated with low levels } \\
\text { of salivary lactoferrin }\end{array}$ \\
\hline Tsang et al. [25] & 1999 & Cohort study & $\begin{array}{l}32 \text { HIV patients, } \\
32 \text { controls }\end{array}$ & $\begin{array}{l}\text { Salivary lysozyme levels were not associated } \\
\text { with oral candidiasis }\end{array}$ \\
\hline Mandel et al. [26] & 1992 & $\begin{array}{l}\text { Case-control } \\
\text { study }\end{array}$ & $\begin{array}{l}78 \text { HIV patients, } \\
27 \text { controls }\end{array}$ & $\begin{array}{l}\text { Oral candidiasis was not associated with salivary } \\
\text { lactoferrin and lysozyme in patients with HIV infection }\end{array}$ \\
\hline Muller et al. [11] & 1992 & $\begin{array}{l}\text { Case-control } \\
\text { study }\end{array}$ & $\begin{array}{l}44 \text { HIV patients, } \\
19 \text { controls }\end{array}$ & $\begin{array}{c}\text { An increase in candidiasis was associated with a decrease } \\
\text { in lactoferrin in HIV-positive patients, but was not } \\
\text { associated with salivary lysozyme levels }\end{array}$ \\
\hline Atkinson et al. [13] & 1990 & $\begin{array}{l}\text { Case-control } \\
\text { study }\end{array}$ & $\begin{array}{l}37 \text { HIV patients, } \\
15 \text { controls }\end{array}$ & $\begin{array}{l}\text { Patients with HIV infection with higher candida counts } \\
\text { had higher salivary lysozyme and salivary lactoferrin }\end{array}$ \\
\hline
\end{tabular}

tions $[2,3]$. There are a variety of defense systems against Candida albicans in the host body, including specific immune system and non-specific immune system. The innate immune system creates a defense barrier against infections [27]. Lactoferrin and salivary lysozyme play an important role in innate immunity. These salivary proteins are produced by the salivary glands, gingival crevicular fluid, and phagocytic cells [9]. When patients with HIV are divided into three groups based on CD4+ cell count, the lowest levels of these anti-microbial proteins are seen in the third stage; when CD4+ cells are less than 200, this indicate that the innate immunity is suppressed at this stage. 54\% and $37 \%$ of the studies showed a direct relationship between lactoferrin and salivary lysozyme with oral candidiasis in patients with HIV infection, respectively, and the rest of the studies revealed no association or reverse relationship. Such an inconsistency of the results could be due to the collection of saliva at different stages of the disease, and different methods of its analyzing. According to studies, in the early stages of HIV infection, with a decrease in number of CD4+ cells, the innate immunity of saliva to compensation increases [28]. The accumulation of lymphocytes and granulocytes in response to candidiasis infections in the tissue produces cytokines and stimulates the production of salivary lysozyme and lactoferrin $[13,19]$. On the other hand, the release of lactoferrin and lysozyme from cytoplasmic granules of macrophage and neutrophils also occurs [29]. However, increasing lactoferrin sometimes does not prevent candidiasis, which is probably due to the emergence of candidate species that have developed a resistance to lactoferrin and lysozyme, as HIV progresses. With a decrease in number of CD4+ cells below $200 \mu \mathrm{g} / \mathrm{ml}$, the host immune system is unable to produce enough lactoferrin and lysozyme [21]. Significant reductions in lactoferrin and salivary lysozyme in the AIDS stage are likely due to reduced production of neutrophils and leukocytes. HIV infection reduces the number of leukocytes and decreases the movement of leukocytes into the oral mucosa affected by candidiasis infection. Decreasing CD4+ 
cells also weakens granulocytes activity, and reduces the release of granules containing immune components [28, 29].

The numerous anti-fungal mechanisms of lactoferrin cause this protein to be used in combination with anti-fungal agents. The use of lactoferrin in combination with fluconazole may be the most effective combination against Candida [30-32].

Our study has some limitations. Firstly, the sample size was limited for some groups, and secondly, our search was limited to English articles, which may consider language bias.

\section{Conclusions}

Understanding of various factors and conditions involved in candida cloning would be broadly related to increasing our understanding of fungal pathogenesis and host defense factors. The results of our study could be useful in diagnosing and designing new strategies for the prevention and treatment of fungal infections in HIV-positive patients. In addition to anti-fungal properties, non-toxicity to human cells could lead to lactoferrin being used in the future as a drug to prevent and treat fungal infections in patients with immunity difficulties.

\section{Conflict of interest}

The authors declare no conflict of interest with respect to the research, authorship, and/or publication of this article.

\section{References}

1. Akpan A, Morgan R. Oral candidiasis. Postgrad Med J 2002; 78: 455 459.

2. Portela MB, Souza IP, Costa EM, Hagler AN, Soares RM, Santos AL. Differential recovery of Candida species from subgingival sites in human immunodeficiency virus positive and healthy children from Rio de Janeiro, Brazil. J Clin Microbiol 2004; 42: 5925-5927.

3. Samaranayake LP, Fidel PL, Naglik JR, et al. Fungal infections associated with HIV infection. Oral Dis 2002; 8: 151-160.

4. Giuseppina C, Giuseppe P, Maria EM. Candidal carriage in the oral cavity of human immunodeficiency virus infected subjects. Oral Surg Oral Med Oral Pathol Oral Radiol Endod 2002; 93: 281-286.

5. Fábián TK, Hermann P, Beck A, Fejérdy P, Fábián G. Salivary defense proteins: their network and role in innate and acquired oral immunity. Int J Mol Sci 2012; 13: 4295-4320.

6. Wiesner J, Vilcinskas A. Antimicrobial peptides: the ancient arm of the human immune system. Virulence 2010; 1: 440-464.

7. Ibrahim HR, Thomas U, Pellegrini A. A helix-loop-helix peptide at the upper lip of the active site cleft of lysozyme confers potent antimicrobial activity with membrane permabilization action. J Biol Chem 2001; 276: 43767-43774.

8. Marquis G, Garzon S, Strykowski H, Auger P. Cell walls of normal and lysozyme damaged blastoconidia of Candida albicans: localization of surface factor 4 antigens and vicinal-glycol staining. Infect Immun 1991; 59: 1312-1318.

9. Farnaud S, Evans RW. Lactoferrin - multifunctional protein with antimicrobial properties. Mol Immunol 2003; 40: 395-405.

10. Verma N, Patil R, Khanna V, Singh V, Tripathi A. Evaluation of salivary flow rate and gustatory function in HIV-positive patients with or without highly active antiretroviral therapy. Eur J Dent 2017; 11: 226-231.

11. Muller F, Holberg-Petersen M, Rollag H, Degre M, Brandtzaeg P, Froland SS. Nonspecific oral immunity in individuals with HIV infection. J Acquir Immune Defic Syndr 1992; 5: 46-51.
12. Lourenço AG, Nakao C, Machado AA, et al. Lactoferrin, a marker for periodontal disease. Curr HIV Res 2013; 11: 220-225.

13. Atkinson JC, Yeh CK, Oppenheim FG, Bermudez D, Baum BJ, Fox PC. Elevation of salivary antimicrobial proteins following HIV-1 infection. J Acquir Immune Defic Syndr 1990; 3: 41-48.

14. Chandrasekar Lakshmi K, Sankarapandiyan S, Nagalingeswaran K, Kindo A, Ganesan N. Oral candidal carriage, salivary lysozyme levels, and their relationship with CD4 count in HIV-infected patients. J Investig Clin Dent 2016; 7: 81-86.

15. Ferreira SM, Gonçalves LS, Torres SR, Nogueira SA, Meiller TF. Lactoferrin levels in gingival crevicular fluid and saliva of HIV-infected patients with chronic periodontitis. J Investig Clin Dent 2015; 6: 16-24.

16. Moher D, Liberati A, Tetzlaff J, Altman DG; PRISMA Group. Preferred reporting items for systematic reviews and meta-analyses: the PRISMA statement. PLoS Med 2009; 6: e1000097.

17. Boudin F, Nie JY, Bartlett JC, Grad R, Pluye P, Dawes M. Combining classifiers for robust PICO element detection. BMC Med Inform Decis Mak 2010; 10: 29.

18. Stang A. Critical evaluation of the Newcastle-Ottawa scale for the assessment of the quality of nonrandomized studies in metaanalyses. Eur J Epidemiol 2010; 25: 603-605.

19. Alves TP, Simões AC, Soares RM, Moreno DS, Portela MB, Castro GF. Salivary lactoferrin in HIV-infected children: correlation with Candida albicans carriage, oral manifestations, HIV infection and its antifungal activity. Arch Oral Biol 2014; 59: 775-782.

20. Laibe S, Biichlé S, Clair S, et al. Increase in lactoferrin and lysozyme local synthesis in human immunodeficiency virus-infected patients with oropharyngeal candidiasis: role of the innate mucosal immunity? Journal de Mycologie Médicale 2005; 15: 69-76.

21. Namikoshi S, Ohshima T, Chiba H, Maeda N. Relationship between oral Candida and salivary antimicrobial proteins in HIV-positive individuals. Journal of Tokyo Medical University 2004; 62: 625-634.

22. Bard E, Laibe S, Clair S, et al. Nonspecific secretory immunity in HIV-infected patients with oral candidiasis. J Acquir Immune Defic Syndr 2002; 31: 276-284.

23. Lin AL, Johnson DA, Patterson TF, et al. Salivary anticandidal activity and saliva composition in an HIV-infected cohort. Oral Microbiol Immunol 2001; 16: 270-278.

24. Van Der Strate BWA, Harmsen MC, The TH, et al. Plasma lactoferrin levels are decreased in end-stage AIDS patients. Viral Immunol 1999; 12: 197-203.

25. Tsang C, Samaranayake L. Salivary lysozyme and related parameters of a predominantly Chinese, HIV-infected cohort in Hong Kong. Oral Dis 1999; 5: 241-246.

26. Mandel ID, Barr CE, Turgeon L. Longitudinal study of parotid saliva in HlV-1 infection. J Oral Pathol Med 1992; 21: 209-213.

27. Medzhitov R, Janeway C. Innate immunity. N Engl J Med 2000; 343 : 338-344.

28. Farah CS, Elahi S, Pang G, et al. T cells augment monocyte and neutrophil function in host resistance against oropharyngeal candidiasis. Infect Immun 2001; 69: 6110-6118.

29. Xu H, Wang X, Veazey RS. Mucosal immunology of HIV infection. Immunol Rev 2013; 254: 10-33.

30. Kuipers ME, de Vries HG, Eikelboom MC, Meijer DKF, Swart PJ. Synergistic fungistatic effects of lactoferrin in combination with antifungal drugs against clinical candida isolates. Antimicrob Agents Chemother 1999; 43: 2635-2641.

31. Naidu AS, Fowler RS, Martinez C, Chen J, Tulpinski J. Activated lactoferrin and fluconazole synergism against Candida albicans and Candida glabrata vaginal isolates. J Reprod Med 2004; 49: 800-807.

32. Samaranayake YH, Samaranayake LP, Pow EH, Beena VT, Yeung KW. Antifungal effects of lysozyme and lactoferrin against genetically similar, sequential Candida albicans isolates from a human immunodeficiency virus-infected southern Chinese cohort. J Clin Microbiol 2001; 39: 3296-3302. 